\title{
INTERNATIONAL STANDARD
}

\section{Lighting of indoor work places}

Éclairage intérieur pour des lieux de travail 


\section{PDF disclaimer}

This PDF file may contain embedded typefaces. In accordance with Adobe's licensing policy, this file may be printed or viewed but shall not be edited unless the typefaces which are embedded are licensed to and installed on the computer performing the editing. In downloading this file, parties accept therein the responsibility of not infringing Adobe's licensing policy. The ISO Central Secretariat accepts no liability in this area.

Adobe is a trademark of Adobe Systems Incorporated.

Details of the software products used to create this PDF file can be found in the General Info relative to the file; the PDF-creation parameters were optimized for printing. Every care has been taken to ensure that the file is suitable for use by ISO member bodies. In the unlikely event that a problem relating to it is found, please inform the Central Secretariat at the address given below.

\section{(C) ISO 2002}

All rights reserved. Unless otherwise specified, no part of this publication may be reproduced or utilized in any form or by any means, electronic or mechanical, including photocopying and microfilm, without permission in writing from either ISO at the address below or ISO's member body in the country of the requester.

ISO copyright office

Case postale $56 \cdot \mathrm{CH}-1211$ Geneva 20

Tel. + 41227490111

Fax + 41227490947

E-mail copyright@iso.ch

Web www.iso.ch

Printed in Switzerland 


\section{Foreword}

ISO (the International Organization for Standardization) is a worldwide federation of national standards bodies (ISO member bodies). The work of preparing International Standards is normally carried out through ISO technical committees. Each member body interested in a subject for which a technical committee has been established has the right to be represented on that committee. International organizations, governmental and non-governmental, in liaison with ISO, also take part in the work. ISO collaborates closely with the International Electrotechnical Commission (IEC) on all matters of electrotechnical standardization.

International Standard ISO 8995 was prepared as Standard CIE S 008/E by the International Commission on Illumination, which has been recognized by the ISO Council as an international standardizing body. It was adopted by ISO under a special procedure which requires approval by at least $75 \%$ of the member bodies casting a vote, and is published as a joint ISO/CIE edition.

The International Commission on Illumination (abbreviated as CIE from its French title) is an organization devoted to international cooperation and exchange of information among its member countries on all matters relating to the science and art of lighting.

Attention is drawn to the possibility that some of the elements of this International Standard may be the subject of patent rights. ISO shall not be held responsible for identifying any or all such patent rights.

International Standard ISO 8995 was prepared jointly by CIE TC 3-21 and ISO/TC 159, Ergonomics, Subcommittee SC 5, Ergonomics of the physical environment.

This second edition cancels and replaces the first edition (ISO 8995:1989), of which it constitutes a technical revision. 
ISO 8995:2002(E)

(Blankpage) 
ISO 8995:2002(E)

Џコ

CIE S 008/E-2001

Standard

\section{Lighting of Indoor Work Places}

Eclairage intérieur pour des lieux de travail

Beleuchtung von Arbeitsplätzen in Innenräumen

CIE Standards are copyrighted and shall not be reproduced in any form, entirely or partly, without the explicit agreement of the CIE. 
ISO 8995:2002(E)

CIE S 008/E-2001

(c) CIE 2001

All rights reserved. Unless otherwise specified, no part of this publication may be reproduced or utilized in any form or by any means, electronic or mechanical, including photocopying and microfilm, without permission in writing from CIE Central Bureau at the address below.

CIE Central Bureau

Kegelgasse 27

A-1030 Vienna

Austria

Tel.: +43171431870

Fax: +431713083818

e-mail: ciecb@ping.at

Web: www.cie.co.at/cie 


\section{Foreword}

Standards produced by the Commission Internationale de l'Éclairage (CIE) are a concise documentation of data defining aspects of light and lighting, for which international harmony requires such unique definition. CIE Standards are therefore a primary source of internationally accepted and agreed data, which can be taken, essentially unaltered, into universal standard systems.

This International Standard was prepared jointly by CIE-TC 3-21 and ISO/TC 159/SC 5. It replaces publication CIE 29.2-1986 and deals with Lighting Requirements for Indoor Work Places.

\section{Table of contents}

FOREWORD ………............................. III

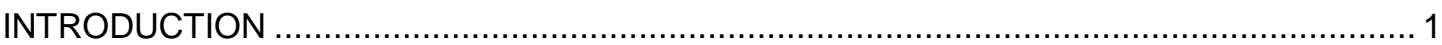

1. SCOPE

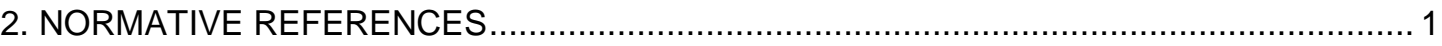

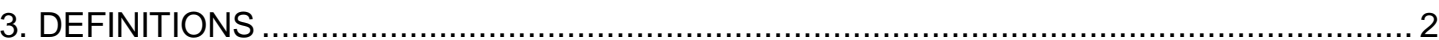

4. LIGHTING DESIGN CRITERIA ........................................................................

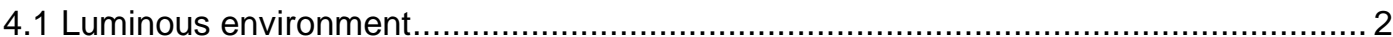

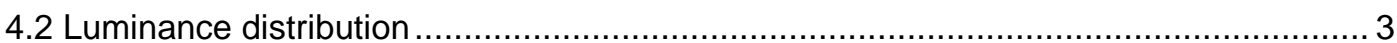

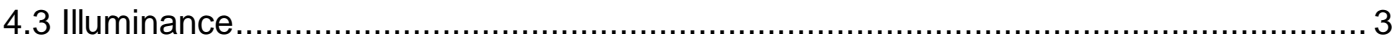

4.3.1 Recommended illuminances at the task area ............................................. 3

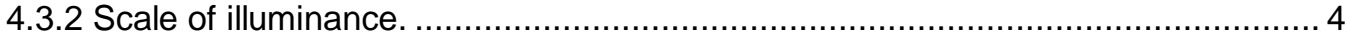

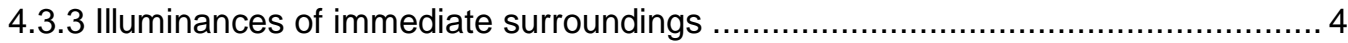

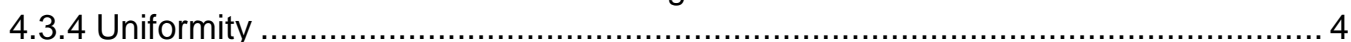

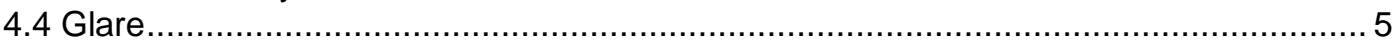

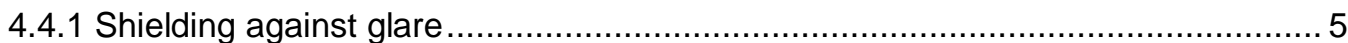

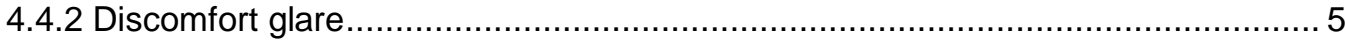

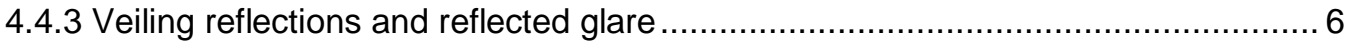

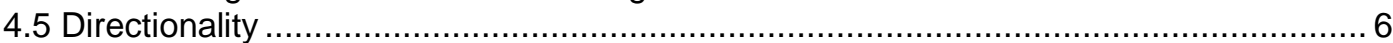

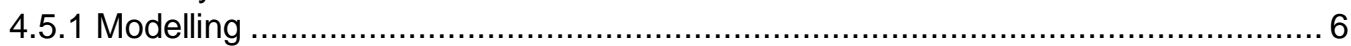

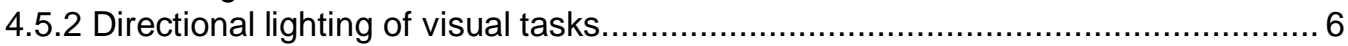

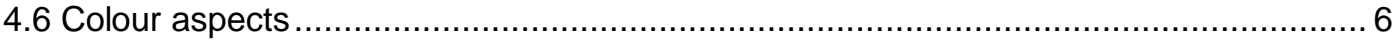

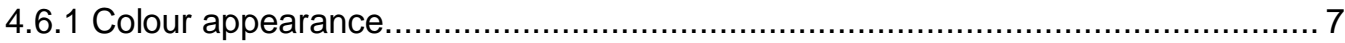

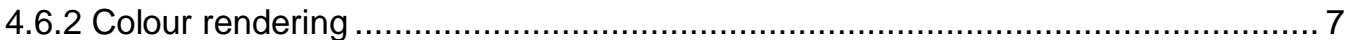

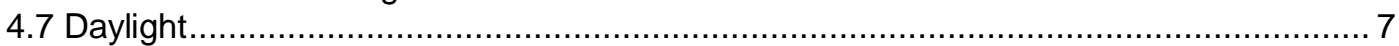

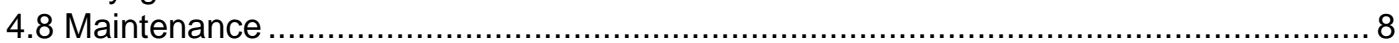

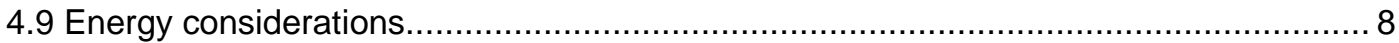

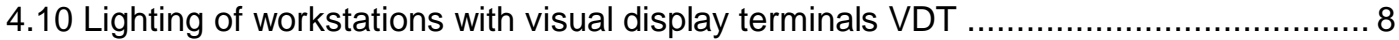

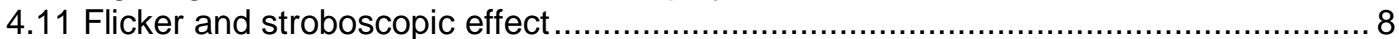

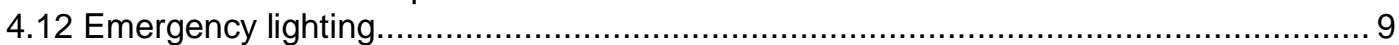

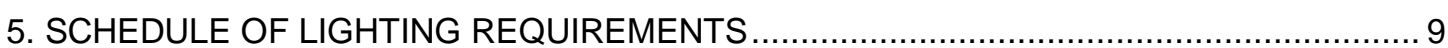

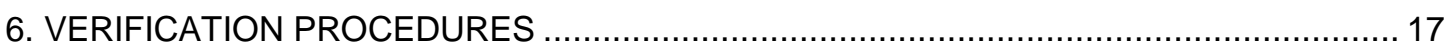

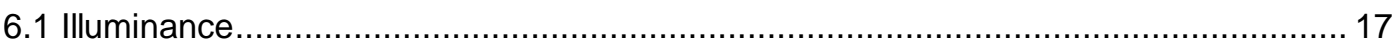

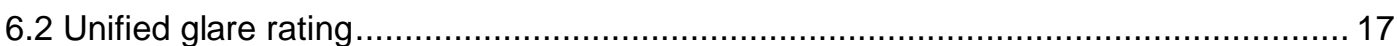

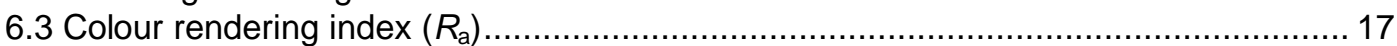

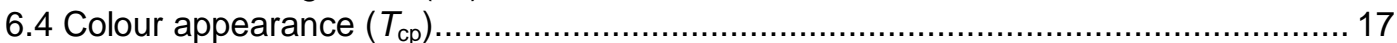

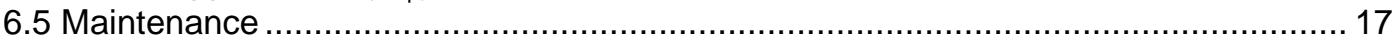

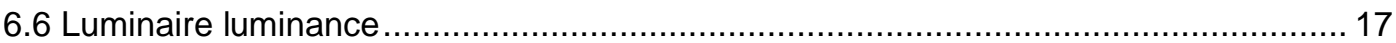

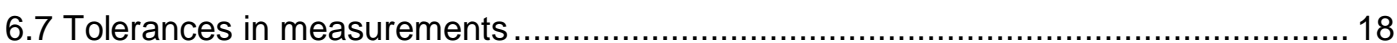

(C) CIE, 2001

(C) CIE, 2001 - All rights reserved III

(C) ISO 2002 - All rights reserved vii 
ISO 8995:2002(E)

CIE S 008/E-2001

(Blankpage) 


\section{LIGHTING OF INDOOR WORK PLACES}

\section{Introduction}

Good lighting will create a visual environment that enables people to see, to move about safely and to perform visual tasks efficiently, accurately and safely without causing undue visual fatigue and discomfort. The illumination may be daylight, electric light or combination of both.

Good lighting requires equal attention to the quantity and quality of the lighting. While the provision of sufficient illuminance on the task is necessary, in many instances the visibility depends on the way in which the light is delivered, the colour characteristics of the light source and surfaces together with the level of glare from the system. In this standard opportunity was taken to specify for various work places and task types not just the illuminance but also the limiting discomfort glare and minimum colour rendering index of the source. Parameters to create comfortable visual conditions are proposed in the body of this standard. The recommended values are considered to represent a reasonable balance, having regard to the requirements for safe, healthy and efficient work performance. The values can be achieved with practical energy efficient solutions.

There are also visual ergonomic parameters such as perceptual ability and the characteristics and attributes of the task, which determine the quality of the operator's visual skills, and hence performance levels. In some cases enhancement of these influencing factors can improve performance without the need to raise illuminance. For example by improving the contrast of the task attributes, enlarging the task by the use of up to date visual aids (glasses) and by the provision of special lighting systems with local directional lighting capability.

\section{Scope}

This standard specifies lighting requirements for indoor work places and for people to perform the visual tasks efficiently, in comfort and safety throughout the whole work period.

This standard does not explain how lighting systems or techniques should be designed to optimise solutions for specific work places. These may be found in the relevant CIE guides and reports.

\section{Normative references}

The following standards contain provisions which, through reference in this text, constitute provisions of this International Standard. At the time of publication, the editions indicated were valid. All standards are subject to revision, and parties to agreements based on this Standard are encouraged to investigate the possibility of applying most recent editions of the standards indicated below. Members of CIE, the International Electrotechnical Commission (IEC) and the International Organization for Standardization (ISO) maintain registers of currently valid international standards.

ISO 3864

ISO 6309

ISO 6385

ISO 9241 Parts $6 / 7 / 8$

CIE $13.3-1995$

CIE $16-1970$

CIE $17.4-1987$

CIE $19.2-1981$

CIE $40-1978$

CIE $58-1983$
Safety colours and safety signs

Fire protection - safety signs

Ergonomic principles in the design of work systems

Ergonomic requirements for office work with visual display terminals

Method of measuring and specifying colour rendering of light sources

Daylight

International lighting vocabulary 4th ed. - equivalent to IEC 50(845)

An analytic model for describing the influence of lighting parameters upon visual performance

Calculations for interior lighting - basic method

Lighting for sports halls 
CIE $60-1984$

CIE 62 - 1984

CIE $96-1992$

CIE $97-1992$

CIE 103/5 - 1993

CIE $117-1995$

CIE $129-1998$
Vision and the visual display unit work station

Lighting for swimming pools

Electric light sources. State of the art - 1991

Maintenance of indoor electric lighting systems

The economics of interior lighting maintenance

Discomfort glare in interior lighting

Guide for lighting of exterior work areas

\section{Definitions}

In general the terms used in this standard are defined in the CIE Lighting Vocabulary (CIE 17.4-1987), but there are few more terms that are defined below:

3.1 visual task: The visual elements of the task to be carried out.

3.2 task area: The partial area in the work place in which the visual task is located and carried out.

3.3 immediate surrounding: A zone of at least $0,5 \mathrm{~m}$ width surrounding the task area within the field of vision.

3.4 maintained illuminance $\left(\overline{E_{\mathrm{m}}}\right)$ : Value below which the average illuminance on the specified surface should not fall.

3.5 unified glare rating (UGR): The CIE discomfort glare measure.

3.6 limiting unified glare rating (UGR $\left.R_{\mathrm{L}}\right)$ : The maximum allowable design UGR value for the lighting installation.

3.7 Shielding angle: the angle measured from the horizontal, down to which the lamp(s) is screened by the luminaire from direct view by an observer.

3.8 Working plane: the reference surface defined as the plane at which work is usually done.

\section{Lighting design criteria}

\subsection{Luminous environment}

Good lighting practice for work places is more than just providing good task visibility. It is essential that tasks are performed easily and in comfort. Thus the lighting must satisfy the quantitative and qualitative aspects demanded by the environment. In general lighting is to ensure:

- visual comfort, where the workers have a feeling of well-being,

- visual performance, where the workers are able to perform their visual tasks, speedily and accurately even under difficult circumstances and during long periods,

- visual safety, to see one's way around and detect hazards. is required.

To satisfy these, attention to all parameters contributing to the luminous environment

The main parameters are:

- luminance distribution,

- illuminance,

- glare,

- directionality of light,

- colour aspect of the light and surfaces,

- flicker,

- daylight,

- maintenance. 
ISO 8995:2002(E)

CIE S 008/E-2001

- safety,

- psycho-physiological aspects such as visual comfort and well-being,

- economy,

- practical experience.

The value of illuminance may be adjusted, by at least one step on the scale of illuminance, if the visual conditions differ from the normal assumptions. The illuminance should be increased when:

- unusually low contrasts are present in the task,

- visual work is critical,

- errors are costly to rectify,

- accuracy or higher productivity is of great importance,

- the visual capacity of the worker is below normal.

The required maintained illuminance may be decreased when:

- the details are of an unusually large size or high contrast,

- the task is undertaken for an unusually short time.

In areas where continuous work is carried out the maintained illuminance shall not be less than 200 lux.

\subsubsection{Scale of illuminance}

A factor of approximately 1,5 represents the smallest significant difference in subjective effect of illuminance. In normal lighting conditions approximately 20 lux of horizontal illuminance is required to just discern features of the human face and is the lowest value taken for the scale of illuminances. The recommended scale of illuminance is:

$$
20 \text { - } 30 \text { - } 50 \text { - } 75 \text { - } 100 \text { - } 150 \text { - } 200 \text { - } 300 \text { - } 500-750 \text { - } 1000 \text { - } 1500 \text { - } 2000-3000 \text { - } 5000 \text { lux. }
$$

\subsubsection{Illuminances of immediate surroundings}

The illuminance of immediate surrounding areas shall be related to the illuminance of the task area and should provide a well-balanced luminance distribution in the field of view.

Rapid spatial changes in illuminances around the task area may lead to visual stress and discomfort.

The maintained illuminance of the immediate surrounding areas may be lower than the task illuminance but shall not be less than the values given in the table below.

\begin{tabular}{|c|c||}
\hline \hline $\begin{array}{c}\text { Task illuminance } \\
\text { lux }\end{array}$ & $\begin{array}{c}\text { Illuminance of immediate surroundings } \\
\text { lux }\end{array}$ \\
\hline$\geq 750$ & 500 \\
\hline 500 & 300 \\
\hline 300 & 200 \\
\hline$\leq 200$ & Same as task illuminance \\
\hline
\end{tabular}

In addition to the task illuminance the lighting shall provide adequate adaptation luminance in accordance with clause 4.2.

\subsubsection{Uniformity}

The uniformity of the illuminance is the ratio of the minimum to average value. The illuminance shall change gradually. The task area shall be illuminated as uniformly as possible. The uniformity of the task illuminance shall not be less than 0,7 . The uniformity of the illuminance of the immediate surrounding areas shall be not less than 0,5 . 


\subsection{Glare}

Glare is the visual sensation produced by bright areas within the field of view and may be experienced either as discomfort glare or disability glare. Glare may also be caused by reflections in specular surfaces usually known as veiling reflections or reflected glare.

It is important to limit the glare to avoid errors, fatigue and accidents.

Disability glare is more common in exterior lighting but may also be experienced from spotlights or large bright sources such as a window in a relatively poorly lit space.

In interior workplaces discomfort glare usually arises directly from bright luminaires or windows. If the discomfort glare limits are met then disability glare is not usually a major problem.

\subsubsection{Shielding against glare}

Glare is caused by excessive luminances or contrasts in the field of view and can impair the vision of objects. It should be avoided for example by suitable shielding of lamps or shading of windows by blinds.

For electric lamps the minimum shielding angle for lamp luminances shall be not less than the values given in the table below:

\begin{tabular}{|c|c||}
\hline \hline $\begin{array}{c}\text { Lamp luminance } \\
\mathrm{kcd} / \mathrm{m}^{2}\end{array}$ & Minimum shielding angle \\
\hline \hline 1 to 20 & $10^{\circ}$ \\
\hline 20 to 50 & $15^{\circ}$ \\
\hline 50 to 500 & $20^{\circ}$ \\
\hline$\geq 500$ & $30^{\circ}$ \\
\hline \hline
\end{tabular}

The above mentioned shielding angle should not be applied to luminaires which do not appear in the field of view of a worker during usual work and/or do not give the worker any noticeable disability glare.

\subsubsection{Discomfort glare}

The discomfort glare rating of the lighting installation shall be determined by the CIE Unified Glare Rating (UGR) tabular method, based on formula:

$$
U G R=8 \cdot \log \left(\frac{0,25}{L_{\mathrm{b}}} \cdot \sum \frac{L^{2} \cdot \omega}{p^{2}}\right)
$$

where

- $\quad L_{b}$ is the background luminance $\left(\mathrm{cd} / \mathrm{m}^{2}\right)$,

- $\quad L \quad$ is the luminance of the luminous parts of each luminaire in the direction of the observer's eye $\left(\mathrm{cd} / \mathrm{m}^{2}\right)$,

- $\quad \omega$ is the solid angle of the luminous parts of each luminaire at the observer's eye (steradian),

- $\quad p$ is the Guth position index for each individual luminaire which relates to its displacement from the line of sight.

Details of the UGR method are given in CIE 117 - 1995.

In this standard all UGR values in clause 5 are based on the standard observer's position which have been validated by the UGR tabular method at a 1:1 spacing to height ratio. The UGR data shall be corrected for the initial luminous flux of the lamps used. If the 
ISO 8995:2002(E)

CIE S 008/E-2001

lighting installation is composed of different types of luminaires with different photometry and/or lamps, the determination of the UGR value shall be applied to every lamp/luminaire combination in the installation. The highest UGR value thus obtained shall be taken as typical value of the entire installation and shall conform to the UGR limit. All assumptions made in the determination of UGR shall be stated in the scheme documentation.

The UGR value of the lighting installation shall not exceed the value given in clause 5 .

Note: The variations of UGR within the room may be determined using the tabular method or the formula for different observer positions.

The values of UGR limits in clause 5 were taken from the UGR scale - where each step in the scale represents one significant change in glare effect and 13 represents the least perceptible discomfort glare.

The UGR scale is: $13-16-19-22-25-28$

\subsubsection{Veiling reflections and reflected glare}

Specular reflections in the visual task, often called veiling reflection or reflected glare, may alter task visibility, usually detrimentally. Veiling reflections and reflected glare may be prevented or reduced by the following measures:

- arrangement of luminaires and work places (avoid placing luminaires in the offending zone),

- surface finish (use low gloss surface materials),

- luminance of luminaires (limit),

- increased luminous area of luminaire (enlarge luminous area),

- ceiling and wall surfaces (lighten, avoid bright spots).

\subsection{Directionality}

Directional lighting may be used to highlight objects, to reveal texture and improve appearance of people within the space. This is described by the term "modelling". Directional lighting of a visual task may also enhance its visibility.

\subsubsection{Modelling}

Modelling refers to the balance between diffuse and directional light. It is a valid criterion of lighting quality in virtually all types of interiors. The general appearance of an interior is enhanced when its structural features, the people and objects within it are lit so that form and texture are revealed clearly and pleasingly. This occurs when the light comes noticeably from one direction; the shadows formed are essential to good modelling and are formed without confusion.

The lighting should not be too directional as it can produce harsh shadows, neither should it be too diffuse or the modelling effect will be lost entirely, resulting in a very dull luminous environment.

\subsubsection{Directional lighting of visual tasks}

Lighting from a specific direction can reveal details within a visual task, increasing their visibility and making the task easier to perform. Particularly important for fine textured tasks and scribes/grooves.

\subsection{Colour aspects}

The colour qualities of a near-white lamp are characterised by two attributes:

- the colour appearance of the lamp itself,

- its colour rendering capabilities, which affect the colour appearance of objects and persons illuminated by the lamp.

These two attributes must be considered separately. 


\subsection{Colour appearance}

The "colour appearance" of a lamp refers to the apparent colour (lamp chromaticity) of the light it emits. It may be described by its correlated colour temperature.

Lamps are usually divided into three groups according to their correlated colour temperature $\left(T_{\mathrm{cp}}\right)$.

\begin{tabular}{||c|c||}
\hline \hline Colour appearance & Correlated colour temperature \\
\hline \hline warm & below $3300 \mathrm{~K}$ \\
\hline intermediate & $3300 \mathrm{~K}$ to $5300 \mathrm{~K}$ \\
\hline cool & above $5300 \mathrm{~K}$ \\
\hline \hline
\end{tabular}

The choice of colour appearance is a matter of psychology, aesthetics and of what is considered to be natural. The choice depends on illuminance, colours of the room and furniture, surrounding climate and the application. In warm climates generally a cooler light colour appearance is preferred, and in cold climates a warmer light colour appearance is preferred.

\subsubsection{Colour rendering}

It is important for both visual performance and the feeling of comfort and well being that colours in the environment of objects and human skin are rendered naturally, correctly and in a way that makes people look attractive and healthy. discriminated.

Safety colours according to ISO 3864 shall always be recognisable and clearly

To provide an objective indication of the colour rendering properties of a light source the general colour rendering index $R_{\mathrm{a}}$ has been introduced. The maximum value of $R_{\mathrm{a}}$ is 100 . This figure decreases with decreasing colour rendering quality.

Lamps with $R_{a}$ less than 80 should not be used in interiors where people work or stay for long periods. Exceptions can be high-bay lighting and outdoor lighting. (Industrial downlights used at mounting height in excess of $6 \mathrm{~m}$.) But even here suitable measure must be taken to ensure that higher colour rendering lamps are used in continually occupied work places and where safety colours have to be recognised.

The recommended minimum value of the general colour rendering index for different types of interiors, tasks or activities are given in clause 5 .

\subsection{Daylight}

Daylight may provide all or part of the lighting for visual tasks.

Daylight varies in level and spectral composition with time and therefore provides variability within an interior. Daylight may create a specific modelling and luminance distribution due to its nearly horizontal flow from side windows. Daylight can also be provided by roof lights and other fenestration elements.

Windows can also provide a visual contact with the outside world, which is preferred by most people. Avoid excessive contrast and thermal discomfort caused by direct sunlight in work areas. Provide adequate sun control such as blinds or shades, so that direct sunlight does not hit workers and/or surfaces within their field of view.

In interiors with side windows the available daylight decreases rapidly with distance from the window. In these interiors the daylight factor should not fall below $1 \%$ on the working plane $3 \mathrm{~m}$ from window wall and $1 \mathrm{~m}$ from side walls. Supplementary lighting should be provided to ensure the required illuminance at the work place and to balance the luminance distribution within the room. Automatic or manual switching and/or dimming can be used to ensure appropriate integration between electric lighting and daylight. 
ISO 8995:2002(E)

CIE S 008/E-2001

To reduce glare from windows, screening shall be provided.

\subsection{Maintenance}

The recommended lighting levels for each task are provided as maintained illuminance. Maintained illuminance depends on the maintenance characteristic of the lamp, the luminaire, the environment and maintenance programme.

The lighting scheme should be designed with overall maintenance factor calculated for the selected lighting equipment, space environment and specified maintenance schedule. The calculated maintenance factor should not be less than 0,70 .

\subsection{Energy considerations}

The lighting installation should meet the lighting requirements of a particular interior, task or activity without waste of energy. However, it is important not to compromise the visual aspects of a lighting installation simply to reduce energy consumption.

This requires the consideration of appropriate lighting systems, equipment, controls and the use of available daylight. In some countries there are limits on the available energy for lighting that should be observed. These limits may be achieved by prudent selection of the lighting system and the use of automatic or manual switching or dimming of the lamps.

\subsection{Lighting of workstations with visual display terminals VDT \\ (also known as visual display units VDU and display screen equipment DSE)}

The lighting for the VDT work stations shall be appropriate for all tasks performed at the work station, e.g. reading from screen, printed text, writing on paper, keyboard work, etc.

For these areas therefore the lighting criteria and systems shall be chosen in accordance with activity area, task type and type of interior from the schedule in clause 5.

The VDT screens and in some circumstances the keyboard can suffer from reflections causing disability and discomfort glare. It is therefore necessary to select, locate and manage the luminaires to avoid disturbing high brightness reflections.

The designer shall determine the offending mounting zone and shall choose suitable luminance controlled equipment and plan mounting positions which will cause no disturbing reflections.

The luminance limits for downward flux of luminaires which maybe reflected in the VDT screens for normal viewing directions are shown in the table below. The limits of the average luminaire luminance are given at elevation angles of $65^{\circ}$ and above from the downward vertical radially around the luminaires for work places where display screens which are vertical or inclined up to $15^{\circ}$ tilt angle are used.

\begin{tabular}{||l|c|c|c||}
\hline \hline Screen classes see ISO 9241-7 & I & II & III \\
\hline Screen quality & good & medium & poor \\
\hline $\begin{array}{l}\text { Limit of average luminance of } \\
\text { luminaires }\end{array}$ & \multicolumn{2}{|c||}{$\leq 1000 \mathrm{~cd} / \mathrm{m}^{2}$} & $\leq 200 \mathrm{~cd} / \mathrm{m}^{2}$ \\
\hline \hline
\end{tabular}

Note: $\quad$ For certain special places using for example sensitive screens or variable inclination the above luminance limits should be applied for lower elevation angles (e.g. $55^{\circ}$ ) of the luminaire.

\subsection{Flicker and stroboscopic effect}

Flicker causes distraction and may give rise to physiological effects such as headaches. The lighting system should be designed to avoid flicker and stroboscopic effects. Stroboscopic 
effects can lead to dangerous situations by changing the perceived motion of rotating or reciprocating machinery.

Note: $\quad$ This can be achieved by use of DC electrical supply or by operating lamps at high frequency (around $30 \mathrm{kHz}$ ) or distribute the connection of the lighting over more than one phase of the supply.

\subsection{Emergency lighting}

Emergency lighting shall be installed, the details are to be found in a separate standard that is under preparation.

\section{Schedule of lighting requirements}

The lighting requirements recommended for various rooms and activities are given in the tables of this clause in the following manner.

Column 1: $\quad$ List of interior (areas) tasks or activities

Column 1 lists those interiors, tasks or activities for which specific requirements are given. If the particular interior, task or activity is not listed, the values given for a similar, comparable situation should be adopted.

Column 2: $\quad$ Maintained illuminance $\left(\overline{E_{\mathrm{m}}}\right.$, lux $)$

Column 2 gives the maintained illuminance on the reference surface for interior, task or activity given in column 1 (see 4.3).

Column 3: $\quad$ Limiting unified glare rating $\left(U G R_{\mathrm{L}}\right)$

Column 3 gives the UGR limits applicable to the situation listed in column 1 , (see 4.4).

Column 4: $\quad$ Minimum colour rendering index $\left(R_{\mathrm{a}}\right)$

Column 4 gives the minimum colour rendering indices for the situation listed in column 1, (see 4.6.2).

Column 5: $\quad$ Remarks

Advice and footnotes are given for exceptions and special applications of the situations listed in column 1.

For VDT applications see 4.10.

THE SCHEDULE OF INTERIORS (AREAS) TASKS AND ACTIVITIES WITH SPECIFICATION OF ILLUMINANCE, GLARE LIMITATION AND COLOUR QUALITY

\begin{tabular}{|l|l|l|l|l|}
\hline Type of interior, task or activity & $\begin{array}{c}\overline{E_{\mathrm{m}}} \\
\text { lux }\end{array}$ & UGR & $R_{\mathrm{a}}$ & Remarks \\
\hline 1. General building areas & & & & \\
\hline Entrance halls & 100 & 22 & 60 & \\
\hline Lounges & 200 & 22 & 80 & \\
\hline Circulation areas and corridors & 100 & 28 & 40 & $\begin{array}{l}\text { At exits and entrances provide a } \\
\text { transition zone and avoid sudden } \\
\text { changes. }\end{array}$ \\
\hline Stairs, escalators, travelators & 150 & 25 & 40 & \\
\hline Loading ramps/bays & 150 & 25 & 40 & \\
\hline Canteens & 200 & 22 & 80 & \\
\hline Rest rooms & 100 & 22 & 80 & \\
\hline Rooms for physical exercise & 300 & 22 & 80 & \\
\hline $\begin{array}{l}\text { Cloakrooms, washrooms, } \\
\text { bathrooms, toilets }\end{array}$ & 200 & 25 & 80 & \\
\hline Sick bay & 500 & 19 & 80 & \\
\hline Rooms for medical attention & 500 & 16 & 90 & $T_{\mathrm{cp}}$ at least $4000 \mathrm{~K}$ \\
\hline Plant rooms, switch gear rooms & 200 & 25 & 60 & \\
\hline
\end{tabular}


ISO 8995:2002(E)

CIE S 008/E-2001

\begin{tabular}{|c|c|c|c|c|}
\hline Type of interior, task or activity & $\begin{array}{c}\overline{E_{\mathrm{m}}} \\
\text { lux }\end{array}$ & $U G R_{L}$ & $R_{\mathrm{a}}$ & Remarks \\
\hline Post room, switchboard & 500 & 19 & 80 & \\
\hline Store, stockrooms, cold store & 100 & 25 & 60 & 200 lux if continuously occupied \\
\hline Dispatch packing handling areas & 300 & 25 & 60 & \\
\hline Control station & 150 & 22 & 60 & 200 lux if continuously occupied \\
\hline \multicolumn{5}{|l|}{ 2. Agriculture building } \\
\hline $\begin{array}{l}\text { Loading and operating of goods } \\
\text { handling equipment and } \\
\text { machinery }\end{array}$ & 200 & 25 & 80 & \\
\hline Building for livestock & 50 & 28 & 40 & \\
\hline Sick animal pens, calving stalls & 200 & 25 & 80 & \\
\hline $\begin{array}{l}\text { Feed preparation, dairy, utensil } \\
\text { washing }\end{array}$ & 200 & 25 & 80 & \\
\hline \multicolumn{5}{|l|}{ 3. Bakeries } \\
\hline Preparation and baking & 300 & 22 & 80 & \\
\hline Finishing, glazing, decorating & 500 & 22 & 80 & \\
\hline \multicolumn{5}{|l|}{$\begin{array}{l}\text { 4. Cement, concrete, \& bricks } \\
\text { industry }\end{array}$} \\
\hline Drying & 50 & 28 & 20 & Safety colours shall be recognisable. \\
\hline $\begin{array}{l}\text { Preparation of materials, work on } \\
\text { kilns and mixers }\end{array}$ & 200 & 28 & 40 & \\
\hline General machine work & 300 & 25 & 80 & For high-bay: see also clause 4.6.2. \\
\hline Rough forms & 300 & 25 & 80 & For high-bay: see also clause 4.6.2. \\
\hline \multicolumn{5}{|l|}{ 5. Ceramics and glass industry } \\
\hline Drying & 50 & 28 & 20 & \\
\hline Preparation, general machine work & 300 & 25 & 80 & For high-bay: see also clause 4.6.2. \\
\hline $\begin{array}{l}\text { Enamelling, rolling, pressing, } \\
\text { shaping simple parts, glazing, } \\
\text { glass blowing }\end{array}$ & 300 & 25 & 80 & For high-bay: see also clause 4.6.2. \\
\hline $\begin{array}{l}\text { Grinding, engraving, glass polishing, } \\
\text { shaping precision parts, } \\
\text { manufacture of glass instruments }\end{array}$ & 750 & 19 & 80 & For high-bay: see also clause 4.6.2. \\
\hline Decorative work & 500 & 19 & 80 & \\
\hline $\begin{array}{l}\text { Grinding of optical glass, crystal } \\
\text { hand grinding and engraving, work } \\
\text { on average goods }\end{array}$ & 750 & 16 & 80 & \\
\hline $\begin{array}{l}\text { Precision work e.g decorative } \\
\text { grinding, hand painting }\end{array}$ & 1000 & 16 & 90 & $T_{\mathrm{cp}}$ at least $4000 \mathrm{~K}$ \\
\hline $\begin{array}{l}\text { Manufacture of synthetic precious } \\
\text { stones }\end{array}$ & 1500 & 16 & 90 & $T_{\mathrm{cp}}$ at least $4000 \mathrm{~K}$ \\
\hline \multicolumn{5}{|l|}{$\begin{array}{l}\text { 6. Chemicals, plastics and rubber } \\
\text { industry }\end{array}$} \\
\hline $\begin{array}{l}\text { Remote operated processing } \\
\text { installations }\end{array}$ & 50 & & 20 & Safety colours shall be recognisable. \\
\hline $\begin{array}{l}\text { Processing installations with limited } \\
\text { manual intervention }\end{array}$ & 150 & 28 & 40 & \\
\hline $\begin{array}{l}\text { Constantly manned work places in } \\
\text { processing installations }\end{array}$ & 300 & 25 & 80 & \\
\hline $\begin{array}{l}\text { Precision measuring rooms, } \\
\text { laboratories }\end{array}$ & 500 & 19 & 80 & \\
\hline Pharmaceutical production & 500 & 22 & 80 & \\
\hline Tyre production & 500 & 22 & 80 & \\
\hline Colour inspection & 1000 & 16 & 90 & $T_{\mathrm{cp}}$ at least $6500 \mathrm{~K}$ \\
\hline Cutting, finishing, inspection & 750 & 19 & 80 & \\
\hline
\end{tabular}


ISO 8995:2002(E)

CIE S 008/E-2001

\begin{tabular}{|c|c|c|c|c|}
\hline Type of interior, task or activity & $\begin{array}{c}\overline{E_{\mathrm{m}}} \\
\operatorname{lux}\end{array}$ & UGR & $R_{\mathrm{a}}$ & Remarks \\
\hline \multicolumn{5}{|l|}{ 7. Electrical industry } \\
\hline Cable and wire manufacture & 300 & 25 & 80 & For high-bay: see also clause 4.6.2. \\
\hline \multicolumn{5}{|l|}{ Winding: } \\
\hline - large coils & 300 & 25 & 80 & For high-bay: see also clause 4.6.2. \\
\hline - medium-sized coils & 500 & 22 & 80 & For high-bay: see also clause 4.6.2. \\
\hline - small coils & 750 & 19 & 80 & For high-bay: see also clause 4.6.2. \\
\hline Coil impregnating & 300 & 25 & 80 & For high-bay: see also clause 4.6.2. \\
\hline Galvanising & 300 & 25 & 80 & For high-bay: see also clause 4.6.2. \\
\hline \multicolumn{5}{|l|}{ Assembly work: } \\
\hline - rough e.g. large transformers & 300 & 25 & 80 & For high-bay: see also clause 4.6.2. \\
\hline - medium e.g. switchboards & 500 & 22 & 80 & \\
\hline - fine e.g telephones & 750 & 19 & 80 & \\
\hline - precision e.g. measuring equipm. & 1000 & 16 & 80 & \\
\hline $\begin{array}{l}\text { Electronic workshops, testing, } \\
\text { adjusting }\end{array}$ & 1500 & 16 & 80 & \\
\hline \multicolumn{5}{|l|}{ 8. Food industry } \\
\hline $\begin{array}{l}\text { Workplaces and zones in breweries, } \\
\text { malting floor, for washing, barrel } \\
\text { filling, cleaning, sieving, peeling, } \\
\text { cooking in preserve and chocolate } \\
\text { factories, work places and zones } \\
\text { in sugar factories, for drying and } \\
\text { fermenting raw tobacco, } \\
\text { fermentation cellar }\end{array}$ & 200 & 25 & 80 & \\
\hline $\begin{array}{l}\text { Sorting and washing of products, } \\
\text { milling, mixing, packing }\end{array}$ & 300 & 25 & 80 & \\
\hline $\begin{array}{l}\text { Work places and zones in slaughter } \\
\text { houses, butchers, dairies mills, on } \\
\text { filtering floor, in sugar refineries }\end{array}$ & 500 & 25 & 80 & \\
\hline $\begin{array}{l}\text { Cutting and sorting of fruit and } \\
\text { vegetables }\end{array}$ & 300 & 25 & 80 & \\
\hline $\begin{array}{l}\text { Manufacture of delicatessen foods, } \\
\text { kitchen }\end{array}$ & 500 & 22 & 80 & \\
\hline $\begin{array}{l}\text { Manufacture work of cigars and } \\
\text { cigarettes }\end{array}$ & 500 & 22 & 80 & \\
\hline $\begin{array}{l}\text { Inspection of glasses and bottles, } \\
\text { product control, trimming, sorting } \\
\text { decoration }\end{array}$ & 500 & 22 & 80 & \\
\hline Laboratories & 500 & 19 & 80 & \\
\hline Colour inspection & 1000 & 16 & 90 & $T_{\text {cp }}$ at least $4000 \mathrm{~K}$ \\
\hline \multicolumn{5}{|l|}{$\begin{array}{l}\text { 9. Foundries and metal casting } \\
\text { plants }\end{array}$} \\
\hline $\begin{array}{l}\text { Mansize underfloor tunnels, cellars } \\
\text { etc. }\end{array}$ & 50 & 28 & 20 & Safety colours shall be recognisable. \\
\hline Platforms & 100 & 25 & 40 & \\
\hline Sand preparation & 200 & 25 & 80 & For high-bay: see also clause 4.6.2. \\
\hline Dressing room & 200 & 25 & 80 & For high-bay: see also clause 4.6.2. \\
\hline Workplaces at cupola and mixer & 200 & 25 & 80 & For high-bay: see also clause 4.6.2. \\
\hline Casting bay & 200 & 25 & 80 & For high-bay: see also clause 4.6.2. \\
\hline Shake out areas & 200 & 25 & 80 & For high-bay: see also clause 4.6.2. \\
\hline Machine moulding & 200 & 25 & 80 & For high-bay: see also clause 4.6.2. \\
\hline Hand and core moulding & 300 & 25 & 80 & For high-bay: see also clause 4.6.2. \\
\hline Die casting & 300 & 25 & 80 & For high-bay: see also clause 4.6.2. \\
\hline Model building & 500 & 22 & 80 & For high-bay: see also clause 4.6.2. \\
\hline
\end{tabular}


ISO 8995:2002(E)

CIE S 008/E-2001

\begin{tabular}{|c|c|c|c|c|}
\hline Type of interior, task or activity & $\begin{array}{c}\overline{E_{\mathrm{m}}} \\
\operatorname{lux}\end{array}$ & UGR & $R_{\mathrm{a}}$ & Remarks \\
\hline \multicolumn{5}{|l|}{ 10. Hairdressers } \\
\hline Hairdressing & 500 & 19 & 90 & \\
\hline \multicolumn{5}{|l|}{ 11. Jewellery manufacturing } \\
\hline Working with precious stones & 1500 & 16 & 90 & $T_{\mathrm{cp}}$ at least $4000 \mathrm{~K}$ \\
\hline Manufacture of jewellery & 1000 & 16 & 90 & \\
\hline Watch making (manual) & 1500 & 16 & 80 & \\
\hline Watch making (automatic) & 500 & 19 & 80 & \\
\hline \multicolumn{5}{|l|}{ 12. Laundries and dry cleaning } \\
\hline Goods in, marking and sorting & 300 & 25 & 80 & \\
\hline Washing and dry cleaning & 300 & 25 & 80 & \\
\hline Ironing, pressing & 300 & 25 & 80 & \\
\hline Inspection and repairs & 750 & 19 & 80 & \\
\hline \multicolumn{5}{|l|}{ 13. Leather industry } \\
\hline Work on vats, barrels, pits & 200 & 25 & 40 & \\
\hline $\begin{array}{l}\text { Fleshing, skiving, rubbing, tumbling } \\
\text { of skins }\end{array}$ & 300 & 25 & 80 & \\
\hline $\begin{array}{l}\text { Saddlery work, shoe manufacture } \\
\text { stitching, sewing, polishing, } \\
\text { shaping, cutting, punching }\end{array}$ & 500 & 22 & 80 & \\
\hline Sorting & 500 & 22 & 90 & $T_{\text {cp }}$ at least $4000 \mathrm{~K}$ \\
\hline Leather dyeing (machine) & 500 & 22 & 80 & \\
\hline Quality control & 1000 & 19 & 80 & \\
\hline Colour inspection & 1000 & 16 & 90 & $T_{\mathrm{cp}}$ at least $4000 \mathrm{~K}$ \\
\hline Shoe making & 500 & 22 & 80 & \\
\hline Glove making & 500 & 22 & 80 & \\
\hline \multicolumn{5}{|l|}{ 14. Metal working and processing } \\
\hline Open die forging & 200 & 25 & 60 & \\
\hline Drop forging, welding, cold forming & 300 & 25 & 60 & \\
\hline $\begin{array}{l}\text { Rough and average machining: } \\
\text { tolerances }>0,1 \mathrm{~mm}\end{array}$ & 300 & 22 & 60 & \\
\hline $\begin{array}{l}\text { Precision machining: grinding: } \\
\text { tolerances }<0,1 \mathrm{~mm}\end{array}$ & 500 & 19 & 60 & \\
\hline Scribing; inspection & 750 & 19 & 60 & \\
\hline Wire \& pipe drawing shapes & 300 & 25 & 60 & \\
\hline Plate machining $\geq 5 \mathrm{~mm}$ & 200 & 25 & 60 & \\
\hline Sheet metalwork <5mm & 300 & 22 & 60 & \\
\hline $\begin{array}{l}\text { Tool making; cutting equipment } \\
\text { manufacture }\end{array}$ & 750 & 19 & 60 & \\
\hline \multicolumn{5}{|l|}{ Assembly: } \\
\hline - rough & 200 & 25 & 80 & For high-bay: see also clause 4.6.2. \\
\hline - medium & 300 & 25 & 80 & For high-bay: see also clause 4.6.2. \\
\hline - fine & 500 & 22 & 80 & For high-bay: see also clause 4.6.2. \\
\hline - precision & 750 & 19 & 80 & For high-bay: see also clause 4.6.2. \\
\hline Galvanising & 300 & 25 & 80 & For high-bay: see also clause 4.6.2. \\
\hline Surface preparation and painting & 750 & 25 & 80 & \\
\hline $\begin{array}{l}\text { Tool, template and jig making, } \\
\text { precision mechanics, micro- } \\
\text { mechanics }\end{array}$ & 1000 & 19 & 80 & \\
\hline \multicolumn{5}{|l|}{ 15. Paper industry } \\
\hline Pulp mills, edge runners & 200 & 25 & 80 & For high-bay: see also clause 4.6.2. \\
\hline $\begin{array}{l}\text { Paper manufacture and processing, } \\
\text { paper and corrugating machines, } \\
\text { cardboard manufacture }\end{array}$ & 300 & 25 & 80 & For high-bay: see also clause 4.6.2. \\
\hline
\end{tabular}




\begin{tabular}{|c|c|c|c|c|}
\hline Type of interior, task or activity & $\begin{array}{c}\overline{E_{\mathrm{m}}} \\
\operatorname{lux}\end{array}$ & $U G R_{L}$ & $R_{\mathrm{a}}$ & Remarks \\
\hline $\begin{array}{l}\text { Standard book binding work, e.g. } \\
\text { folding, sorting, gluing, cutting, } \\
\text { embossing, sewing }\end{array}$ & 500 & 22 & 60 & \\
\hline \multicolumn{5}{|l|}{ 16. Power stations } \\
\hline Fuel supply plant & 50 & 28 & 20 & Safety colours shall be recognisable. \\
\hline Boiler house & 100 & 28 & 40 & \\
\hline Machine halls & 200 & 25 & 80 & For high-bay: see also clause 4.6.2. \\
\hline $\begin{array}{l}\text { Auxiliary rooms, e.g pump rooms, } \\
\text { condenser rooms, switchboard, } \\
\text { etc. }\end{array}$ & 200 & 25 & 60 & \\
\hline Control rooms & 500 & 16 & 80 & $\begin{array}{l}\text { 1. Control panels are often vertical. } \\
\text { 2. Dimming may be required. } \\
\text { 3. For VDT work see clause } 4.10 \text {. }\end{array}$ \\
\hline \multicolumn{5}{|l|}{ 17. Printers } \\
\hline $\begin{array}{l}\text { Cutting, gilding, embossing, block } \\
\text { engraving, work on stones and } \\
\text { platens, printing machines, matrix } \\
\text { making }\end{array}$ & 500 & 19 & 80 & \\
\hline Paper sorting and hand printing & 500 & 19 & 80 & \\
\hline Type setting, retouching, lithography & 1000 & 19 & 80 & \\
\hline $\begin{array}{l}\text { Colour inspection in multi-coloured } \\
\text { printing }\end{array}$ & 1500 & 16 & 90 & $T_{\mathrm{cp}} 5000 \mathrm{~K}$ \\
\hline Steel and copper engraving & 2000 & 16 & 80 & For directional light see clause 4.5.2. \\
\hline \multicolumn{5}{|l|}{ 18. Iron and steel works } \\
\hline $\begin{array}{l}\text { Production plants without manual } \\
\text { Intervention }\end{array}$ & 50 & 28 & 20 & Safety colours shall be recognisable. \\
\hline $\begin{array}{l}\text { Production plants with occasional } \\
\text { manual operation }\end{array}$ & 150 & 28 & 40 & \\
\hline $\begin{array}{l}\text { Production plants with continuous } \\
\text { manual operation }\end{array}$ & 200 & 25 & 80 & For high-bay: see also clause 4.6.2. \\
\hline Slab store & 50 & 28 & 20 & Safety colours shall be recognisable. \\
\hline Furnaces & 200 & 25 & 20 & Safety colours shall be recognisable. \\
\hline Mill train, coiler, shear line & 300 & 25 & 40 & \\
\hline Control platforms, control panels & 300 & 22 & 80 & \\
\hline Test, measurement and inspection & 500 & 22 & 80 & \\
\hline $\begin{array}{l}\text { Underfloor man sized tunnels belt } \\
\text { sections, cellars etc. }\end{array}$ & 50 & 28 & 20 & Safety colours shall be recognisable. \\
\hline \multicolumn{5}{|l|}{ 19. Textile industry } \\
\hline $\begin{array}{l}\text { Workplace and zones in baths, bale } \\
\text { opening }\end{array}$ & 200 & 25 & 60 & \\
\hline $\begin{array}{l}\text { Carding, washing, ironing, drawing, } \\
\text { combing, sizing, card cutting, pre- } \\
\text { spinning, jute and hemp spinning }\end{array}$ & 300 & 22 & 80 & \\
\hline $\begin{array}{l}\text { Spinning, plying, reeling, winding } \\
\text { warping, weaving, braiding, } \\
\text { knitting }\end{array}$ & 500 & 22 & 80 & Prevent stroboscopic effects. \\
\hline $\begin{array}{l}\text { Sewing, fine knitting, taking up } \\
\text { stitches }\end{array}$ & 750 & 22 & 90 & \\
\hline Manual design, drawing patterns & 750 & 22 & 90 & $T_{\mathrm{cp}}$ at least $4000 \mathrm{~K}$ \\
\hline Finishing, dyeing & 500 & 22 & 80 & \\
\hline Drying room & 100 & 28 & 60 & \\
\hline Automatic fabric printing & 500 & 25 & 80 & \\
\hline Burling, picking, trimming & 1000 & 19 & 80 & \\
\hline Colour inspection, fabric control & 1000 & 16 & 90 & $T_{\mathrm{cp}}$ at least $4000 \mathrm{~K}$ \\
\hline Invisible mending & 1500 & 19 & 90 & $T_{\mathrm{cp}}$ at least $4000 \mathrm{~K}$ \\
\hline
\end{tabular}


ISO 8995:2002(E)

CIE S 008/E-2001

\begin{tabular}{|c|c|c|c|c|}
\hline Type of interior, task or activity & $\begin{array}{l}\overline{E_{\mathrm{m}}} \\
\operatorname{lux}\end{array}$ & $U G R_{\llcorner}$ & $R_{\mathrm{a}}$ & Remarks \\
\hline Hat manufacturing & 500 & 22 & 80 & \\
\hline \multicolumn{5}{|l|}{ 20. Vehicle construction } \\
\hline Body work and assembly & 500 & 22 & 80 & \\
\hline $\begin{array}{l}\text { Painting, spraying chamber, } \\
\text { polishing chamber }\end{array}$ & 750 & 22 & 80 & \\
\hline Painting: touch-up, inspection & 1000 & 16 & 90 & $T_{\mathrm{cp}}$ at least $4000 \mathrm{~K}$ \\
\hline Upholstery manufacture (manned) & 1000 & 19 & 80 & \\
\hline Final inspection & 1000 & 19 & 80 & \\
\hline \multicolumn{5}{|l|}{$\begin{array}{l}\text { 21. Wood working \& furniture } \\
\text { industry }\end{array}$} \\
\hline $\begin{array}{l}\text { Automatic processing e.g. drying } \\
\text { plywood manufacturing }\end{array}$ & 50 & 28 & 40 & \\
\hline Steam pits & 150 & 28 & 40 & \\
\hline Saw frame & 300 & 25 & 60 & Prevent stroboscopic effects. \\
\hline $\begin{array}{l}\text { Work at joiner's bench, gluing, } \\
\text { assembly }\end{array}$ & 300 & 25 & 80 & \\
\hline Polishing, painting, fancy joinery & 750 & 22 & 80 & \\
\hline $\begin{array}{l}\text { Work on wood working machines } \\
\text { e.g. turning, fluting, dressing, } \\
\text { rebating, grooving, cutting, } \\
\text { sawing, sinking }\end{array}$ & 500 & 19 & 80 & Prevent stroboscopic effects. \\
\hline $\begin{array}{l}\text { Selection of veneer woods, } \\
\text { maquetry, inlay work }\end{array}$ & 750 & 22 & 90 & $T_{\mathrm{cp}}$ at least $4000 \mathrm{~K}$ \\
\hline Quality control & 1000 & 19 & 90 & $T_{\mathrm{cp}}$ at least $4000 \mathrm{~K}$ \\
\hline \multicolumn{5}{|l|}{ 22. Offices } \\
\hline Filing, copying, circulation, etc. & 300 & 19 & 80 & \\
\hline $\begin{array}{l}\text { Writing, typing, reading, data } \\
\text { processing }\end{array}$ & 500 & 19 & 80 & For VDT-work see clause 4.10. \\
\hline Technical drawing & 750 & 16 & 80 & \\
\hline CAD workstation & 500 & 19 & 80 & For VDT-work see clause 4.10. \\
\hline Conference and meeting rooms & 500 & 19 & 80 & Lighting should be controllable. \\
\hline Reception desk & 300 & 22 & 80 & \\
\hline Archives & 200 & 25 & 80 & \\
\hline \multicolumn{5}{|l|}{ 23. Retailing } \\
\hline Sales area small & 300 & 22 & 80 & \\
\hline Sales area large & 500 & 22 & 80 & \\
\hline Till area & 500 & 19 & 80 & \\
\hline Wrapper table & 500 & 19 & 80 & \\
\hline \multicolumn{5}{|l|}{ 24. Restaurants and hotels } \\
\hline $\begin{array}{l}\text { Reception/cashier desk, porters } \\
\text { desk }\end{array}$ & 300 & 22 & 80 & \\
\hline Kitchen & 500 & 22 & 80 & \\
\hline $\begin{array}{l}\text { Restaurant, dining room, function } \\
\text { room }\end{array}$ & 200 & 22 & 80 & $\begin{array}{l}\text { The lighting should be designed to } \\
\text { create intimate atmosphere. }\end{array}$ \\
\hline Self-service restaurant & 200 & 22 & 80 & \\
\hline Buffet & 300 & 22 & 80 & \\
\hline Conference rooms & 500 & 19 & 80 & Lighting should be controllable. \\
\hline Corridors & 100 & 25 & 80 & $\begin{array}{l}\text { During night time lower levels are } \\
\text { acceptable. }\end{array}$ \\
\hline \multicolumn{5}{|l|}{ 25. Places of entertainment } \\
\hline Theatres \& concert halls & 200 & 22 & 80 & \\
\hline Multi purpose halls & 300 & 22 & 80 & \\
\hline
\end{tabular}




\begin{tabular}{|c|c|c|c|c|}
\hline Type of interior, task or activity & $\begin{array}{l}\overline{E_{\mathrm{m}}} \\
\operatorname{lux}\end{array}$ & $U G R$ & $R_{\mathrm{a}}$ & Remarks \\
\hline Practice rooms, dressing rooms & 300 & 22 & 80 & $\begin{array}{l}\text { Glare free mirror lighting for make-up } \\
\text { required. }\end{array}$ \\
\hline Museums (general) & 300 & 19 & 80 & $\begin{array}{l}\text { Lighting to suit the display requirements, } \\
\text { protect against radiation effects. See } \\
\text { Museum Lighting Guide. }\end{array}$ \\
\hline \multicolumn{5}{|l|}{ 26. Libraries } \\
\hline Bookshelves & 200 & 19 & 80 & \\
\hline Reading area & 500 & 19 & 80 & \\
\hline Counters & 500 & 19 & 80 & \\
\hline \multicolumn{5}{|l|}{ 27. Public car parks (indoor) } \\
\hline In/out ramps (during the day) & 300 & 25 & 40 & Safety colours shall be recognisable. \\
\hline In/out ramps (at night) & 75 & 25 & 40 & Safety colours shall be recognisable. \\
\hline Traffic lanes & 75 & 25 & 40 & Safety colours shall be recognisable. \\
\hline Parking areas & 75 & 28 & 40 & $\begin{array}{l}\text { A high vertical illuminance increases } \\
\text { recognition of peoples faces and } \\
\text { therefore the feeling of safety. }\end{array}$ \\
\hline Ticket office & 300 & 19 & 80 & $\begin{array}{l}\text { 1. Avoid reflections in the windows. } \\
\text { 2. Prevent glare from outside. }\end{array}$ \\
\hline \multicolumn{5}{|l|}{ 28. Educational buildings } \\
\hline Play school room & 300 & 19 & 80 & \\
\hline Nursery class & 300 & 19 & 80 & \\
\hline Nursery craft room & 300 & 19 & 80 & \\
\hline Classrooms, tutorial rooms & 300 & 19 & 80 & Lighting should be controllable. \\
\hline $\begin{array}{l}\text { Classroom for evening classes and } \\
\text { adults education }\end{array}$ & 500 & 19 & 80 & \\
\hline Lecture hall & 500 & 19 & 80 & Lighting should be controllable. \\
\hline Black board & 500 & 19 & 80 & Prevent specular reflections. \\
\hline Demonstration table & 500 & 19 & 80 & In lecture halls 750 lux \\
\hline Art and craft rooms & 500 & 19 & 80 & \\
\hline Art rooms in art schools & 750 & 19 & 90 & $T_{\text {cp }}>5000 \mathrm{~K}$ \\
\hline Technical drawing rooms & 750 & 16 & 80 & \\
\hline Practical rooms and laboratories & 500 & 19 & 80 & \\
\hline Teaching workshop & 500 & 19 & 80 & \\
\hline Music practice rooms & 300 & 19 & 80 & \\
\hline Computer practice rooms & 500 & 19 & 80 & For VDT-work see clause 4.10 \\
\hline Language laboratory & 300 & 19 & 80 & \\
\hline Preparation rooms and workshops & 500 & 22 & 80 & \\
\hline $\begin{array}{l}\text { Student common rooms and } \\
\text { assembly halls }\end{array}$ & 200 & 22 & 80 & \\
\hline Teachers rooms & 300 & 22 & 80 & \\
\hline $\begin{array}{l}\text { Sports halls, gymnasiums and } \\
\text { swimming pools }\end{array}$ & 300 & 22 & 80 & $\begin{array}{l}\text { For public access facilities see } \\
\text { CIE } 58 \text { - } 1983 \text { and CIE } 62 \text { - } 1984 .\end{array}$ \\
\hline \multicolumn{5}{|l|}{ 29. Health care premises } \\
\hline Waiting rooms & 200 & 22 & 80 & Illuminance at floor level \\
\hline Corridors: during the day & 200 & 22 & 80 & Illuminance at floor level \\
\hline Corridors: during the night & 50 & 22 & 80 & Illuminance at floor level \\
\hline Day rooms & 200 & 22 & 80 & Illuminance at floor level \\
\hline Staff office & 500 & 19 & 80 & \\
\hline Staff rooms & 300 & 19 & 80 & \\
\hline \multicolumn{5}{|l|}{ Wards } \\
\hline - General lighting & 100 & 19 & 80 & Illuminance at floor level \\
\hline - Reading lighting & 300 & 19 & 80 & \\
\hline - Simple examination & 300 & 19 & 80 & \\
\hline Examination and treatment & 1000 & 19 & 90 & \\
\hline Night lighting, observation lighting & 5 & 19 & 80 & \\
\hline
\end{tabular}


ISO 8995:2002(E)

CIE S 008/E-2001

\begin{tabular}{|c|c|c|c|c|}
\hline Type of interior, task or activity & $\begin{array}{c}\overline{E_{\mathrm{m}}} \\
\operatorname{lux}\end{array}$ & $U G R_{L}$ & $R_{\mathrm{a}}$ & Remarks \\
\hline Bathrooms and toilets for patients & 200 & 22 & 80 & \\
\hline Examination room general & 500 & 19 & 90 & \\
\hline Ear and eye examination & 1000 & & 90 & Local examination luminaire \\
\hline $\begin{array}{l}\text { Reading and colour vision test with } \\
\text { vision charts }\end{array}$ & 500 & 16 & 90 & \\
\hline $\begin{array}{l}\text { Scanners with image enhancers and } \\
\text { television systems }\end{array}$ & 50 & 19 & 80 & For VDT work see clause 4.10. \\
\hline Dialysis rooms & 500 & 19 & 80 & \\
\hline Dermatology rooms & 500 & 19 & 90 & \\
\hline Endoscopy rooms & 300 & 19 & 80 & \\
\hline Plaster rooms & 500 & 19 & 80 & \\
\hline Medical baths & 300 & 19 & 80 & \\
\hline Massage and radiotherapy & 300 & 19 & 80 & \\
\hline Pre-op and recovery rooms & 500 & 19 & 90 & \\
\hline Operating theatre & 1000 & 19 & 90 & \\
\hline Operating cavity & Special & & & $\overline{E_{\mathrm{m}}}=10000 \operatorname{lux}-100000 \operatorname{lux}$ \\
\hline \multicolumn{5}{|l|}{ Intensive care } \\
\hline - General lighting & 100 & 19 & 90 & At floor level \\
\hline - Simple examinations & 300 & 19 & 90 & At bed level \\
\hline - Examination and treatment & 1000 & 19 & 90 & At bed level \\
\hline - Night watch & 20 & 19 & 90 & \\
\hline \multicolumn{5}{|l|}{ Dentists } \\
\hline - General lighting & 500 & 19 & 90 & $\begin{array}{l}\text { Lighting should be glare free for the } \\
\text { patient. }\end{array}$ \\
\hline - At the patient & 1000 & & 90 & Local examination luminaire \\
\hline - Operating cavity & 5000 & & 90 & $\begin{array}{l}\text { Values higher than } 5000 \text { lux may be } \\
\text { required. }\end{array}$ \\
\hline - White teeth matching & 5000 & & 90 & $T_{\mathrm{cp}} \geq 6000 \mathrm{~K}$ \\
\hline Colour inspection (laboratories) & 1000 & 19 & 90 & $T_{\mathrm{cp}} \geq 5000 \mathrm{~K}$ \\
\hline Sterilisation rooms & 300 & 22 & 80 & \\
\hline Disinfection rooms & 300 & 22 & 80 & \\
\hline Autopsy rooms and mortuaries & 500 & 19 & 90 & \\
\hline Autopsy table and dissecting table & 5000 & & 90 & $\begin{array}{l}\text { Values higher than } 5000 \text { lux may be } \\
\text { required. }\end{array}$ \\
\hline \multicolumn{5}{|l|}{ 30. Airports } \\
\hline $\begin{array}{l}\text { Arrival and departure halls, baggage } \\
\text { claim areas }\end{array}$ & 200 & 22 & 80 & For high-bay: see also clause 4.6.2. \\
\hline $\begin{array}{l}\text { Connecting areas, escalators, } \\
\text { travelators }\end{array}$ & 150 & 22 & 80 & \\
\hline Information desks, check-in desks & 500 & 19 & 80 & For VDT work see clause 4.10. \\
\hline Customs and passport control desks & 500 & 19 & 80 & Vertical illuminance is important. \\
\hline Waiting areas & 200 & 22 & 80 & \\
\hline Luggage store rooms & 200 & 28 & 60 & \\
\hline Security check areas & 300 & 19 & 80 & For VDT-work see clause 4.10. \\
\hline Air traffic control tower & 500 & 16 & 80 & $\begin{array}{l}\text { 1. Lighting should be dimmable. } \\
\text { 2. For VDT work see clause } 4.10 \text {. } \\
\text { 3. Glare from daylight should be avoided. }\end{array}$ \\
\hline Air traffic rooms & 500 & 16 & 80 & $\begin{array}{l}\text { 1. Lighting should be dimmable. } \\
\text { 2. For VDT work see clause } 4.10 \text {. }\end{array}$ \\
\hline Testing and repair hangars & 500 & 22 & 80 & For high-bay: see also clause 4.6.2. \\
\hline Engine test areas & 500 & 22 & 80 & For high-bay: see also clause 4.6.2. \\
\hline Measuring areas in hangars & 500 & 22 & 80 & For high-bay: see also clause 4.6.2. \\
\hline $\begin{array}{l}\text { Platforms and passenger subways } \\
\text { (underpasses) }\end{array}$ & 50 & 28 & 40 & \\
\hline Ticket hall and concourse & 200 & 28 & 40 & \\
\hline $\begin{array}{l}\text { Ticket and luggage offices and } \\
\text { counters }\end{array}$ & 300 & 19 & 80 & \\
\hline
\end{tabular}




\begin{tabular}{|l|c|l|l|l|}
\hline Type of interior, task or activity & $\begin{array}{c}\overline{E_{\mathrm{m}}} \\
\operatorname{lux}\end{array}$ & UGR & $R_{\mathrm{a}}$ & Remarks \\
\hline Waiting rooms & 200 & 22 & 80 & \\
\hline $\begin{array}{l}\text { 31. Churches, mosques, } \\
\text { synagogues and temples }\end{array}$ & & & & \\
\hline Body of church & 100 & 25 & 80 & \\
\hline Chair, altar, pulpit & 300 & 22 & 80 & \\
\hline
\end{tabular}

\section{Verification procedures}

\subsection{Illuminance}

The illuminance shall be measured at specified points on the relevant areas. The readings shall not be less than that calculated for the point.

The maintained illuminance shall be calculated from measured values on the same grid points as used in the design calculation and the value shall be not less than that specified for the task.

For repeat measurements the same points shall be used.

\subsection{Unified glare rating}

Authenticated UGR data produced by the tabular method at $1: 1$ spacing to height ratio in accordance with Publication CIE 117 - 1995 shall be provided for the luminaire/scheme by the manufacturer of the luminaire. The installation layout and the surface finishes shall be checked against the design assumptions.

The installation shall be in accordance with the design assumptions.

\subsection{Colour rendering index $\left(R_{\mathrm{a}}\right)$}

Authenticated $R_{\mathrm{a}}$ data shall be provided for the lamps used in the scheme by the manufacturer of the lamps. The lamps shall be checked against the design specifications and shall have an $R_{\mathrm{a}}$ not less than the value specified in the design.

The lamps shall be as specified in the design.

\subsection{Colour appearance $\left(T_{\mathrm{cp}}\right)$}

Authenticated $T_{\mathrm{cp}}$ value shall be provided for the lamps in the scheme by manufacturer of the lamps. The $T_{\mathrm{cp}}$ value of the lamps shall be not less than the value specified in the design.

\subsection{Maintenance}

The designer shall:

- state the maintenance factor and list all assumptions made in the derivation of the value,

- verify the lighting equipment suitable for the application environment. Prepare a comprehensive maintenance schedule to include frequency of lamp replacement, luminaire and room surface cleaning intervals and cleaning method.

\subsection{Luminaire luminance}

The average luminance of the luminous part of the luminaire shall be measured and/or calculated radially in the C-plane at intervals of $15^{\circ}$ starting at $0^{\circ}$ and the elevation in $\gamma$-angles of $65^{\circ}, 75^{\circ}$ and $85^{\circ}$. Normally the manufacturer of the luminaire shall provide these data based on maximum (lamp/luminaire) output. The values shall not exceed the limits specified in clause 4.10 . 
ISO 8995:2002(E)

CIE S 008/E-2001

\subsection{Tolerances in measurements}

There can be many factors which can cause disparity between the calculated prediction and the measured performance of a lighting installation. The main reason for this is that, even if the calculation process is of the highest possible accuracy, it is assumed that all the individual lamps, circuits and luminaires provide an identical photometric performance. This is clearly impossible and some tolerance must be expected. The magnitude of the difference based on practical experience expected to be within $10 \%$ for illuminance and luminance measures. 
Copies of CIE Publications are available from the National Committees of most CIE member countries. Purchasers in other countries may obtain them from the CIE Central Bureau, Kegelgasse 27, A-1030 Wien, Austria.

\author{
CIE Central Bureau \\ Kegelgasse 27 \\ A-1030 Vienna \\ Austria
}

Tel.: +43171431870

Fax: +431713083818

e-mail: ciecb@ping.at

WWW: http://www.cie.co.at/cie/ 
ISO 8995:2002(E)

ICS 13.180; 91.160 .10

Price based on 18 pages

C ISO 2002 - All rights reserved 